\title{
EFL Teachers' Approaches for Continuing Professional Development
}

\author{
Fitri Aprianti ${ }^{1}$, Eline Rozaliya Winarto ${ }^{1}$ and Dila Charisma ${ }^{1}$ \\ ${ }^{1}$ Universitas Muhammadiyah Cirebon, Indonesia \\ (fitri.aprianti@umc.ac.id)
}

\begin{abstract}
Continuing professional development (CPD) is imperative for teachers. English language teachers are not exceptions. In continuing their professional development, teachers actually have flexibility to choose either training or self-directed CPD approach. Therefore, it is assumed that depending on the gender and the career developmental stage that they are in, teachers may choose different CPD approach. Thus, this study was aimed to see the relationship between teachers' career developmental stage, gender and their selection of CPD approaches. In order to achieve that, this study employed descriptive quantitative approach. The participant involved were 54 EFL teachers in Majalengka, West Java. The data were collected by using questionnaires. Chi-square was used in order to test the three hypotheses. The result revealed that the teachers mainly showed positive comments on CPD. Furthermore, it was found that there was a significant relationship between the teachers' career developmental stages and CPD approaches. On the other hand, the findings signified that there was no relationship between gender of the teachers and their CPD approaches. As the recommendation it is expected that the teachers could maintain and regulate their commitment on continuing professional development. In addition, the government, especially the Indonesian Ministry of Education and Culture is also expected to provide wider variety of professional development approaches so as to bridge the diverse preferences for continuing professional development (CPD) of the teachers in Indonesian setting.
\end{abstract}

Keywords: Continuing Professional Development; EFL Teachers; CPD approaches.

Teachers are important people. By this it means that quality of education can only be as good as the quality of the teachers that are working within it (Forde, et.al 2006; Richards and Farrell, 2006). It is stated that the best ways to enhance that quality is through continuing professional development (CPD). At this stage, CPD requires teachers to continuously extend their learning opportunities in order to enhance their creative and reflective capacities so that it can strengthen their practice as professional educators (Forde et.al, 2006). Yet, as always, when it comes to the complex notion of learning, then it means that we are dealing 
with numbers of traits. Thus, depending on the traits that teachers have, teacher may choose and even need different CPD approaches (Qahtani, 2015).

Forde et.al (2006), see also Richards and Farrell, (2006), for example, classify CPD approaches themselves into two broad classes; those are training and self-directed CPD approaches. By this it means that teaches can either learn through practical apprenticeship (guided by mentor or expert teacher) or by individual trial-and-error (Dede, 2006 pg. 177-178). Dede (2006) further stated that each of the approaches has its own strength and weaknesses in consequences it may suit different traits, needs and purposes. Then, again, the issue that may arise is how to match the right CPD approaches with the suitable teachers' traits, needs and purposes.

\section{Continuing Professional Development}

Language teacher should start to put professional development into priority. The reason for that is because the urgency of continuing professional development (CPD) does not only rely on enhancing the quality of teaching and learning process but also for forging identity of the teachers as professional educators (Forde, et.al 2006). Thus, Coldron and Smith (1999, in Forde, et.al. 2006) state that teachers are always placed in a continuous process professional development right since the beginning and during their careers as teachers.

In addition, Richards and Farrell (2005) also identify two broad classes within the scope of CPD learning approaches. Those are training and self-directed learning. Training is a form of CPD approaches which is typically aimed at short-term period and immediate goal (Ibid, pg. 3). Dede (2006) finds that there are two distinct characteristics of this program, the first one is the existence of expert teacher or mentor, and the second one is the availability of fix-learning schedule. On the other hand, self-directed learning is a form of CPD approaches where the teachers are assumed to take responsibility of their own learning. By this it means that teachers will define, manage and control their own learning (ibid).

Thus, it can be concluded that the investment in teachers' professional development programs and activities appear to be crucial. Teachers can select any of those program based on their goals and needs. Yet, it is stated that selecting CPD approach is a tricky business to do as it involves numbers of trait, thus two of the traits, which are teachers' career developmental stage and gender will be elaborated in the following sub-title (Qahtani, 2015).

\section{Teachers' Career Development and Gender}

There are several traits that are attached to teachers. Two of the traits that need be taken into consideration are teachers' career development stage and gender. Richards and Farrell (2005) state that those traits are classified as important dimensions in teachers' professional development. Super (2005 as cited in Andersen and Vandehey, 2012), states that teachers can actually be classified into three different groups. Those groups are:

a. Establishment Group

b. Maintenance Group, and

c. Disengagement Group

Super (2005 as cited in Andersen and Vandehey, 2012), states that each of the classes has its own distinct characteristics. Firstly, teachers that are classified into establishment group are considered as the teacher who have just recently enter teaching profession, thus, they are less familiar with the occupational duty that they have. The next group, which is Maintenance group, refers to teachers who have mingled with the teaching profession and thus have a greater understanding of their profession. Usually, at this stage they are already able to nurture other teachers in enhancing their duty as teachers. Finally, the disengagement group refers to teachers who are near to retirement period. The characteristics of this group are first, the focus of working 
become lessens and second, the aim of their learning tends to be focused on reflection.

It is assumed that different career development group requires different needs and goals. Andersen and Vandehey (2012) also state that they may have different preferences of learning as well. Thus, this classification of teacher was used in this research.

The other under-debated trait is gender. It is assumed that male used to be the most active person when it comes to the work field, yet, others believe that nowadays there are numbers of women who are pursuing career as educators as well, thus; the fashion may be changing (Andersen and Vandehey, 2012; Forde et.al, 2006). Therefore, this study also takes teachers' gender trait in order to see its relationship with the selection of CPD approaches.

Numbers of studies have actually been conducted in order to answer that matter (Levenberg \& Caspi, 2010 and Azman, et al, 2010). Firstly, the research that comes from Levenberg \& Caspi (2010), for example, shows that there is a significant relationship between certified and uncertified teacher with their selection of CPD approach. In this case, the result shows that the uncertified teachers tend to see CPD as lifelong learning and thus informal or self-directed CPD is mainly preferred by them. Lastly, Azman et al (2010) show that there is a significant relationship between level of experience and the selection of media used for CPD. It is stated that novice teachers tend to choose online media such as collaboration via blogs to help enhance skills that are critical for them.

Although these studies have exemplified numbers of CPD approaches, but it seems that these studies still have left one major gap. That gap is in a form of insufficient of information regarding of whether or not there is a significant relationship between teachers' career development stage and gender with teacher' selection of CPD approaches. Thus, referring to that problem, it can be concluded that the study on EFL teachers' preferences in choosing CPD approaches needs to be conducted. As the result, this study was intended to answer the following questions.

1. How do the EFL teachers perceive the needs for continuing professional development?

2. Is there a significant difference of teachers from different career developmental groups in their selection of CPD approaches?

3 . Is there a significant difference of male and female teachers in their selection of CPD approaches?

Based on the preceding research questions, it can be seen that this study is limited to study the whether teachers, either classified by career developmental grouping or gender, do differ in choosing types of CPD approach that they would like to conduct. Theoretically, the study is expected to enrich blended approaches of continuing professional development in Indonesia. Practically, for professions and institutions, the study is expected to help English language teachers to find wider possibilities in continuing professional development in which teacher could continue to develop their professionalism either through training or self-directed CPD.

\section{Method}

The research design used for this study was descriptive quantitative study. At this stage the focus of descriptive quantitative research is to look out for relationships between the existing variables in a given situation (Creswell, 2012).

In the present study, the target population was all public junior and senior high school EFL teachers in Majelengka, sub district, Majalengka regency, West Java. It means that each of the target samples has the same opportunity to be involved in the study. Yet, from the total 76 EFL teachers only 57 EFL teachers participated in the study. It is also found that out of these 57 teachers, only 54 completed usable questionnaires.

Questionnaires were used to collect 
data from the respondents. It included three parts. The first part was concerned with the background variables of the teachers. The second part of the questionnaire was aimed asked teachers to present their perceptions on continuing professional development. Lastly, the third part of the questionnaires contained question regarding types of $\mathrm{CPD}$ approach that teacher prefer to do.

Each of the total nine schools was approached by the researcher personally. The questionnaire was distributed during the working days. The questionnaire was filled in complete anonymity in order to present the confidentiality of the sample study. Some of the questionnaires were completed on the spot while others were sent through electronic messenger.

The first hypothesis was tested by applying chi-square test of one variable case. On the other hand, the last two hypotheses were tested via chi-square of independence of categorical variables. The null hypotheses were rejected or not rejected, depending on whether the calculated expected ratio was significant of the probability level of 0.05 (or 5\%).

\section{Results and Discussion}

\section{Teacher and Perception of Continuing Professional Development}

The first research question was intended to see teachers and their perception of the notion continuing professional development. In order to get the expected information, the study used independent chi-square with one independent variable (teachers) and three independent variables (their responses to as for, against or undecided regarding the need to continuing professional development). The result of the study was as follows.
The finding shows that there was a significant relationship between teachers and their preference on continuing professional development. This conclusion was proven from the result of the hypothesis testing as shown in the table above. This finding also indicated that that the proportion of teachers who show positive comments on the needs of teachers to continue their professional development was high. It reached about $90.74 \%$ from overall teachers' comment.

The result was also consistent with Levenberg \& Caspi (2010) and Azman, et.al, (2010) who show that there is an increasing awareness of the teachers to continue their professional development. Forde (2006) also state that teachers, in nature, will know that they need to continuously develop their professionalism. One of the major factors that may drive teacher to do this is as a means of forging professional identity as an educator itself. Richards and Farrell also adds that the need to continue professional development even become greater for English language teacher in which teachers are dealing with language teaching and learning which is full with dynamicity and changing.

\section{Teachers' Career Development Stage and CPD approaches}

The second research question was intended to see whether there is relationship between teachers in different career developmental stages and their preference on $\mathrm{CPD}$ approach. In order to answer this research problem, chi-square was used. The computation involved three independent variables, namely Establishment Group, Maintenance Group and Disengagement Group, and two independent variables such as (their preference: training or

Table 1. Chi-square test on teachers' perception regarding the need for continuing PD

Ho: There is no relationship between teachers and their perception on continuing professional development.

\begin{tabular}{|l|l|l|l|l|l|l|l|}
\hline & For & Against & $\begin{array}{l}\text { Unde- } \\
\text { cided }\end{array}$ & Total & df & Critical Value & P \\
\hline Teachers & 49 & 0 & 5 & 54 & 2 & 5.991 & 0,05 \\
\hline
\end{tabular}

Expected Value (X2) $=80.99$ (Ho is rejected, Expected Value $>$ Critical Value) 
Table 2. Chi-square test on teachers with different career developmental stage and their selection of CPD approaches Ho: There is no relationship between teachers' career developmental stage and their selection of CPD approaches.

\begin{tabular}{llllllll}
\hline $\begin{array}{l}\text { CD TPD } \\
\text { Type }\end{array}$ & E & M & D & Total & df & Critical Value & P \\
\cline { 1 - 5 } Training & 12 & 19 & 3 & 34 & 2 & 5.991 & 0,05 \\
\cline { 1 - 5 } Self-directed & 4 & 4 & 12 & 20 & & \\
\hline Total & 16 & 23 & 15 & 54 & & \\
\hline
\end{tabular}

self-directed CPD approach). The result of the study was as follow

The effects of teachers' career developmental stage or group were significant for the selection of CPD approaches needed. This conclusion was proven from the result of the hypothesis testing as shown in the table above. The findings also showed that the proportions of teachers who prefer to follow training program were dominated by the teachers from the establishment and maintenance group. On the other hand, selfdirected learning was mostly chosen by the teachers from disengagement group.

This finding seems to be in line with Super's theory (2005) which highlights that individuals that are from different career developmental group or stage may need different treatment including how they learn. Super (2005) predicts that teachers on disengagement group who are likely to take retirement would likely to do much more reflection on everyday experience through self-directed PD rather than get involved in strictly structured training professional development program. Furthermore, this

Table 3. Chi-square test on gender and teachers' selection of CPD approaches.

Ho: There is no relationship between gender and the selection of CPD approaches.

\begin{tabular}{|l|l|l|}
\hline CD TPD Type & Male & Female \\
\hline Training & 11 & 23 \\
\hline Self-directed & 8 & 12 \\
\hline Total & 19 & 35 \\
\hline
\end{tabular}

Expected Value (X2) $=0.07$ (Ho is accepted, Expected Value $<$ Critical Value) finding also seems to be in line with Garner (1995, cited in Forde et.al, 2006) who finds that new or novice teacher, in this case the establishment group, tend to treat professional training and education as what they mostly need.

\section{Gender and CPD approaches}

The last research question was intended to see teachers whether there is relationship gender and teachers' preference on CPD approach. In order to find it, chi-square was used. The computation involved two independent variables (male and female) and two independent variables (their preference: training or self-directed CPD approach). The result of the study was as follow

In contrast with the last two results, at this stage it was found that there is no significant relationship between gender and the teachers' selection on CPD approaches. This was proven from the hypothesis testing as shown in the table above.

This finding seems to be in line with Super' theory which was renewed in 2005 (cited in Andersen \& Vandehey, 2012) who state that nowadays gender variable does not likely to affect individual choices on career development, in this case CPD approaches.

\section{Conclusion}

This paper has examined the need for EFL teachers to continue their professional development as well as their preference on choosing CPD approach that suits their current need. Thus, it can be concluded that the notion of the importance of continuing 
professional development has also emerged in Indonesian context. It is known that continuing professional development could not only assist teacher to enhance their ability in teaching but also have contributed to shape their identity as professional teachers.

More specifically, the study has firstly revealed that there was a significant relationship between teachers and their perception on continuing professional development. Teachers mainly show positive comments that professional development needs to be continuously conducted. Secondly, it was found that teachers' career developmental stage affects their selection of CPD approaches. Finally, the study shows that the influence of gender did not affect the level of teachers' perception.

\section{References}

Andersen, P. and Vandehey, M. (2012). Career Counselling and Development in Global Economy. Canada: Nelson Education.

Azman, H., Ya'acob, A. and Thang, S. M. (2010). Blogging in teacher professional development: Its role in building computer-assisted language teaching skills: International Journal of Education and Development using Information and Communication Technology (IJEDICT), 6(3), 73-87.

Creswell, J. W. (2012). Educational Research; Planning, Conducting, and Evaluating Quantitative and Qualitative Research. USA: Pearson.

Cowan, J. and Westwood J. (2006). Collaborative and Reflective Professional Development. Active Learning in Higher Education, 7(1), 63-71. (RCS/ SAM).

Dede, C. (2006). Online Professional Development for Teachers: Emerging Models and Methods. Cambridge: Harvard Education Press.
Fraenkel, J. R., Wallen, N. E. \& Hyun, H. H (2012). How to Design and Evaluate Research in Education 8th Edition. New York: McGraw Hill Company.

Forde, C. et.al (2006). Professional Development Reflection and Inquiry. London: Paul Chapman Publishing.

Liu, W., Carr, R., \& Strobel, J. (2009). Extending teacher professional development through an online learning community: A case study. Journal of Educational Technology Development and Exchange, 2(1), 99-112.

Richards J. C \& Farrell T. S. C. (2005). Professional Development for Language Teachers. Cambridge: Cambridge University Press.

Peraturan Menteri Pendidikan dan Kebudayaan No. 20 Tahun 2003. (2003). Tentang Sistem Pendidikan Nasional. Jakarta: Kementrian Pendidikan Kebudayaan Republik Indonesia.

Peraturan Menteri Pendidikan dan Kebudayaan No. 14 Tahun 2005. (2005). Tentang Guru dan Dosen. Jakarta: Kementrian Pendidikan Kebudayaan Republik Indonesia. 
ELLITE $\mid \begin{aligned} & \text { Joural of English Language, } \\ & \text { Liternture }\end{aligned}$

Volume 06, No. 1, May 2021 


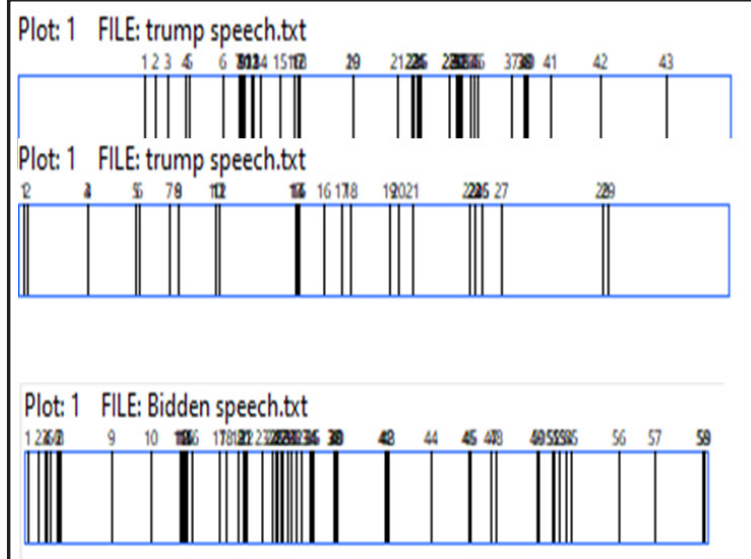

Figure 1. The distribution of the commissive speech acts found in Trump and Bidden's speech 
ELLITE $\mid \begin{aligned} & \text { Joural of English Language, } \\ & \text { Liternture }\end{aligned}$

Volume 06, No. 1, May 2021 
